\title{
Meningkatkan Keterampilan Proses Sains Pada Pelajaran Tema 5 Melalui Model Pembelajaran Problem Based Learning Siswa Kelas IV SDN 1 Sembalun Bumbung Lombok Utara
}

\author{
Muhamad ridwan Habibi \\ habibi@nusantaraglobal.ac.id
}

\begin{abstract}
Abstrak: Penelitian ini dilatar belakangi oleh keadaan model pembelajaran yang masih berpusat kepada guru, sehingga pembelajaran tidak memperlihatkan keaktifan dan membuat siswa mudah jenuh dalam belajar. Berdasarkan latar belakang tersebut, peneliti melakukan tindakan perbaikan dengan menerapkan model pembelajaran Problem based learning (PBL). Tujuan yang ingin di capai dari penelitian ini adalah untuk mengetahui peningkatan keterampilan proses sains pada pelajaran tema 5 siswa kelas IV dengan penerapan model pembelajaran Problem based learning (PBL). Jenis penelitian ini adalah Penelitian Tindakan Kelas dengan metode deskriptif. Subjek penelitian ini adalah seluruh siswa kelas IV SDN 1 Sembalun Bumbung Lombok Utara. Variabel penelitian ini adalah model pembelajaran Problem based learning (PBL) dan dan keterampilan proses sains pada pelajaran tema 5 kelas IV. Prosedur penelitian dilakukan dalam dua siklus, masing-masing siklus terdiri dari 4 tahapan yaitu: 1) perencanaan, 2) pelaksanaan, 3) pengamatan 4) refleksi. Teknik pengumpulan data menggunakan Observasi, angket dan Tes Lembar observasi digunakan untuk melihat kegiatan mengajar guru, lembar angket digunakan untuk melihat keterampilan proses sains pada pelajaran tema 5 dan lembar tes digunakan untuk melihat hasil belajar siswa. Hasil persentase Penerapan model pembelajaran Problem based learning (PBL) dengan rancangan pembelajaran siklus II pada penelitian ini pada ketegori baik dan dapat meningkatkan aktivitas keterampilan proses sains pada pelajaran tema 5 siswa kelas IV SDN 1 Sembalun Bumbung Lombok Utara. Hal ini dibuktikan dengan aktivitas siswa pada siklus I sebesar $65 \%$ yang berkategori cukup aktif dan aktivitas siswa pada siklus II sebesar $91 \%$ yang berkategori aktif.
\end{abstract}

\section{Kata Kunci: Problem based learning (PBL), Keterampilan Proses Sains, Pelajaran Tema 5}

\section{PENDAHULUAN}

Permasalahan yang dialami oleh peserta didik dalam kegiatan belajar, diantaranya adalah merasa bosan. Salah satu faktor yang menyebabkan siswa sering merasa bosan dan tidak memahami materi pelajaran adalah penyampaian materi pelajaran yang kurang menarik dan kurangnya komunikasi antara guru dengan siswa selama proses pembelajaran. Untuk itu perlu dicari solusi yang tepat untuk mengatasi masalah tersebut, misalnya dengan menggunakan strategi pembelajaran yang mengarah pada keaktifan siswa.

Pembelajaran diartikan sebagai seperangkat tindakan yang dirancang untuk mendukung proses belajar siswa, dengan memperhatikan kejadian-kejadian ekstrim yang berperanan terhadap rangkaian kejadiankejadian yang berlangsung dialami siswa. Pembelajaran merupakan usaha pendidikan yang dilaksanakan secara sengaja, tersusun sistematis dengan tujuan yang telah dirancang terlebih dahulu sebelum proses dilaksanakan, serta pelaksanaanya terkendali atau teratur (Miarso, 2007).

Ciri-ciri pembelajaran yang menarik adalah upaya sadar, disengaja, bahkan direncakan dengan baik, pembelajaran harus melibatkan siswa untuk belajar, tujuan pembelajaran harus ditetapkan terlebih dahulu sebelum proses dilaksanakan, dan pelaksanaannya terkendali, baik isinya, waktu 
proses, maupun hasilnya yang tersusun dalam perangkat pembelajaran (Sireger dkk, 2010).

Pembelajaran yang berlangsung di sekolah sudah pasti tidak terlepas dari peraturan dan kurikulum yang telah ditentukan. Saat ini pendidikan di Indonesia sudah menerepkan Kurikulum 2013 yang berbasis pada pembelajaran tematik. Pelaksanaan kurikulum 2013 menjadikan pendidikan tingkat Sekolah Dasar/Madrasah Ibtidaiyah sudah menggunakan pembelajaran terpadu/tematik. Pembelajaran terpadu/tematik adalah suatu sistem pembelajaran yang mana memungkinkan siswasiswa secara individu atau berkelompok dapat aktif dalam mencari, menggali, dan menemukan konsep serta prinsip keilmuan secara holistik, bermakna, dan autentik (Kadir dkk, 2014).

Pembelajaran tematik juga dapat diartikan sebagai pembelajaran yang menggunakan tema dengan mengaitkan antara beberapa isi materi pelajaran, baik dalam satu bidang studi atau pun lebih dengan dihubungkan pada pengalaman kehidupan sehari-hari siswa sehingga dapat memberikan pengalaman bermakna bagi siswa (Kadir dkk, 2014).

Pembelajaran tematik pada jenjang kelas IV MI/SD terbagi dalam 9 tema. Tema 5 pada mata pelajaran tematik jenjang kelas IV MI bertema "Pahlawanku" yang memuat mata pelajaran IPA dan IPS. Mata pelajran IPA yang terdapat dalam tema 5 memuat materi sifat-sifat cahaya. Mata pelajaran IPS dalam tema 5 menjelaskan pahlawan-pahlawan pada masa kerajaan Hindu, atau Budha atau Islam, namun pada tema 5 subtema 1 pembelajaran 1 menjelaskan kepahlawanan raja Purnawarman.

Proses pembelajaran disekolah tidak selalu berjalan baik, banyak kesulitan belajar yang ditemui oleh siswa. Kesulitan belajar dapat diartikan suatu kondisi dalam suatu proses belajar yang ditandai dengan adanya hambatan-hambatan tertentu dalam mencapai tujuan pembelajaran (Bahri, 2014).

Hasil belajar merupakan tolok ukur keberhasilan kegiatan belajar mengajar. Hasil belajar juga dikatakan sebagai hasil akhir dari proses belajar mengajar di kelas serta merupakan perwujudan dari kemampuan diri yang optimal setelah menerima pelajaran. Hasil belajar memuat kemampuan yang dimiliki siswa setelah siswa menerima pengalaman belajar (Sudjana, 2010).

Pengalaman belajar pada kegiatan belajar mengajar yang melibatkan fisik, mental dan sosial siswa yang berakibat pada peningkatan pemahaman siswa terhadap konsep yang dipelajari. Peran guru sebagai seorang pendidik diharapkan mampu merancang pembelajaran yang baik untuk mengatasi kesulitan belajar siswa. Karakteristik siswa, karakteristik materi pembelajaran menjadi pertimbangan oleh guru sebelum memulai pembelajaran untuk menyiapkan pembelajaran yang menyenangkan dan dapat mencapai tujuan pembelajaran. Guru dituntut dapat memilih model pembelajaran yang dapat memacu semangat setiap siswa untuk aktif ikut dalam pengalaman belajarnya (Rusman, 2012).

Banyak model pembelajaran yang menekankan pada keaktifan siswa dalam proses pembelajaran, diantaranya adalah Problem Based Learning (PBL). Problem Based Learning (PBL) adalah rangkaian aktivitas pembelajaran yang menekankan kepada proses penyesuaian masalah yang dihadapi secara ilmiah (Sanjaya, 2010).

Sedangkan menurut Kemendikbud (2014) Problem based learning (PBL) merupakan sebuah pendekatan pembelajaran yang menyajikan maslah kontekstual sehingga merangsang siswa untuk belajar.

Riyanto (2010) menyatakan bahwa problem based learning (PBL) memfokuskan pada siswa dengan mengarahkan siswa menjadi pembelajar yang mandiri dan terlibat langsung secara aktif dalam pembelajaran berkelompok. Model ini membantu siswa untuk mengembangkan berpikir siswa dalam mencari pemecahan masalah melalui pencarian data sehingga diperoleh solusi untuk suatu masalah dengan rasional dan autentik. Hal tersebut diharapkan mampu merangsang siswa untuk berpikir dan mampu mengembangkan 
kemandirian belajar sekaligus belajar bersama dengan kelompoknya.

Model pembelajaran problem based learning ini mempunyai banyak kelebihan dibanding dengan model pembelajaran konvensional. Peneliti juga melihat model pembelajaran problem based learning menitik beratkan pada proses pembelajaran yang diharapkan dapat meningkatkan hasil belajar siswa, sehingga model pembelajaran problem based learning dapat dijadikan sebagai salah satu solusi guru dalam mengatasi permasalahan yang terjadi pada siswa (Kurniasih, 2014).

Melalui model pembelajaran problem based learning (PBL) siswa akan dilatih untuk tidak menggantungkan sepenuhnya kegiatan pembelajaran pada guru, sehingga kemandirian belajar siswa akan muncul. Siswa akan terdorong untuk aktif di dalam pembelajaran, menantang siswa untuk berpikir, memotivasi siswa untuk terus mencari tahu, dan menimbulkan proses belajar yang menyenangkan. Pada akhirnya, siswa mampu menerapkan pengetahuan yang mereka dapatkan dalam kehidupan sehari-hari.

Berdasarkan hasil wawancara dengan para siswa kelas IV SDN 1 Sembalun Bumbung Lombok Utara, mayoritas siswa sangat tertarik mempelajari IPA, namun belum difasilitasi dengan pengalaman langsung di lapangan dan permasalahan sehari-hari yang dijumpai siswa. Siswa juga masih terlihat sangat bergantung pada guru dikarenakan sumber belajar masih terbatas pada buku paket IPA maupun LKS. Kemudian berdasarkan hasil wawancara dengan guru kelas IV SDN 1 Sembalun Bumbung Lombok Utara, guru belum pernah mengimplementasikan model problem based learning (PBL). Hal tersebut disebabkan oleh wawasan guru mengenai problem based learning (PBL) baik secara teoritik maupun praktik masih kurang. Guru juga merasa nyaman dengan metode yang selama ini digunakan yaitu cermah, tanya jawab, atau penugasan. Selain itu, guru belum memahami manfaat problem based learning (PBL). yang dapat melatih kemandirian belajar siswa. Oleh karena itu, dibutuhkan gambaran empiris agar guru mampu melihat gambaran problem based learning (PBL) di dalam pembelajaran secara langsung.

Berdasarkan uraian yang telah dikemukakan di atas, perlu diadakan perbaikan pembelajaran melalui penerapan model problem based learning (PBL) untuk Meningkatkan keterampilan proses sains pada pelajaran tema 5 siswa kelas IV SDN 1 Sembalun Bumbung Lombok Utara.

Rumusan masalah dalam penelitian ini adalah: 1) Bagaimana penerapan model pembelajaran problem based learning pada pelajaran tema 5 siswa kelas IV SDN 1 Sembalun Bumbung Lombok Utara; 2) Bagaimana hasil belajar siswa setelah penerapan model problem based learning pada pelajaran tema 5 siswa kelas IV SDN 1 Sembalun Bumbung Lombok Utara. Sedangkan tujuan dalam penelitian ini adalah: 1) Mendeskripsikan penerapan model Problem Based Learning pada pelajaran tema 5 siswa kelas IV SDN 1 Sembalun Bumbung Lombok Utara; 2) Mendeskripsikan hasil belajar siswa setelah penerapan model problem based learning pada pelajaran tema 5 siswa kelas IV SDN 1 Sembalun Bumbung Lombok Utara.

\section{METODE PENELITIAN}

Jenis penelitian yang digunakan dalam penelitian ini adalah Penelitian Tindakan Kelas (PTK). Menurut Arikunto (2014). Penelitian tindakan kelas merupakan suatu pencermatan terhadap kegiatan belajar berupa sebuah tindakan, yang sengaja dimunculkan dan terjadi pada sebuah kelas secara bersama. Tindakan tersebut diberikan oleh atau atas arahan dari guru yang kemudian dilakukan oleh siswa. Tahapan yang dilalui dalam PTK, yaitu: a) perencanaan, b) pelaksanaan tindakan, c) pengamatan, d) refleksi.

Tempat penelitian di kelas IV SDN 1 Sembalun Bumbung Lombok Utara yang dilaksanakan pada semester genap tahun ajaran 2019/2020. Subjek dalam penelitian ini adalah guru dan siswa kelas IV SDN 1 Sembalun Bumbung Lombok Utara. Adapun jumlah siswa 
kelas IV yaitu 23 orang orang yang terdiri dari 10 orang siswa perempuan dan 13 orang siswa laki-laki. Metode penelitian yang dilakukan dalam penelitian ini adalah metode penelitian deskriptif. Variabel penelitian ini adalah model pembelajaran model problem based learning (PBL) dan keterampilan proses sains pada pelajaran tema 5 kelas IV.

Analisis data observasi dan tes diolah dengan menggunakan rumus:

$N P=R \div S M \times 100$

Keterangan:

$\mathrm{NP}=$ Nilai presentase yang dicari

$\mathrm{R}=$ Skor mentah yang diperoleh siswa

$\mathrm{SM}=$ Skor maksimum

Ideal $100=$ Bilangan tetap ( sumber: Ngalim, 2013)

Tabel 1. Skala Penilaian

\begin{tabular}{|c|c|}
\hline Nilai & Keterangan \\
\hline $81-100 \%$ & Baik Sekali \\
\hline $61-80 \%$ & Baik \\
\hline $41-60 \%$ & Cukup \\
\hline $21-40 \%$ & Kurang \\
\hline$<20 \%$ & Kurang Sekali \\
\hline
\end{tabular}

(sumber: Arikunto, 2014)

Kriteria keberhasilan pada penelitian ini dapat dilihat dari meningkatnya kemampuan berpikir kritis siswa dari siklus I ke siklus selanjutnya yaitu dengan rata-rata hasil lembar observasi dan tes minimal mencapai $61 \%$. Peneliti merencanakan setiap siklus dua kali tatap muka dengan alokasi waktu $2 \times 35$ menit. Teknik pengumpulan data menggunakan Observasi, angket dan Tes Lembar observasi digunakan untuk melihat kegiatan mengajar guru, lembar angket digunakan untuk melihat keterampilan proses sains pada pelajaran tema 5 dan lembar tes digunakan untuk melihat hasil belajar siswa.

\section{HASIL Dan PEMBAHASAN}

Data mengenai aktivitas guru selama proses pembelajaran pada setiap siklus nilai rataratanya berbeda dapat dilihat pada Tabel 1 .
Tabel 1. Data Hasil Observasi Aktivitas Guru SDN 1 Sembalun Bumbung Tahun Pelajaran 2019/2020

\begin{tabular}{|l|l|c|c|}
\hline \multirow{2}{*}{ No } & \multicolumn{2}{|c|}{ Indikator yang diamati } & \multicolumn{2}{|c|}{ Skor } \\
\cline { 3 - 4 } & & Siklus I & Siklus II \\
\hline 1 & Membangkitkan minat dan motivasi siswa dalam belajar & 2 & 5 \\
\hline 2 & Membimbing siswa dalam belajar & 3 & 5 \\
\hline 3 & Mampu menciptakan suasana yang kondusif & 3 & 4 \\
\hline 4 & Penggunaan model problem based learning (PBL) & 4 & 5 \\
\hline 5 & Guru aktif selama proses pembelajaran berlangsung & 3 & 3 \\
\hline 6 & Guru bersama membuat kesimpulan & 3 & 5 \\
\hline \multicolumn{2}{|c|}{ Jumlah } & 18 & 27 \\
\hline \multicolumn{2}{c|}{ Skor rata-rata } & 3 & 4,5 \\
\hline Kategori & Cukup Baik & Sangat Baik \\
\hline
\end{tabular}

Berdasarkan hasil penelitian yang dilakukan pada siklus I dan siklus II terjadi peningkatan skor rata-rata aktivitas guru, yakni dari 3 pada siklus I yang berkategori cukup baik, hal ini terjadi karena guru tidak mampu memaksimalkan waktu yang ada sehingga ada beberapa indikator yang belum terlaksana. Kekurangan yang terjadi pada siklus I yaitu : 1) Guru kurang membangkitkan minat dan motivasi siswa dalam belajar. 2) Guru kurang aktif membimbing siswa agar tidak terpengaruh dengan suasana di luar kelas. 3) Guru kurang aktif membimbing siswa agar tidak mengerjakan pekerjaan lain. 4) Guru belum mampu mengendalikan kondisi yang mengganggu proses dalam belajar. 5) Guru belum mampu menciptakan kondisi belajar yang menyenangkan. 6) Guru kurang berdiskusi dengan siswa. 7) Guru kurang memberikan kesempatan kepada siswa untuk mengemukakan pendapatnya. 8) Guru kurang memberikan kesempatan kepada siswa menanggapi pendapat dari temanya. Setelah melakukan perbaikan pada poin-poin di atas, maka terjadi peningkatan pada siklus II sehingga memperoleh hasil rata-rata skor aktivitas sebesar 4,5 dengan kategori sangat baik. Hal ini juga disebabkan karena guru telah maksimal membimbing dan memfasilitasi siswa yang benar-benar membutuhkan bimbingan secara merata (tidak selalu yang pintar) serta memotivasi siswa dalam mengeluarkan pendapat dan menyimpulkan materi, aktivitas siswa selama mengikuti proses pembelajaran dengan menggunakan model problem based 
learning (PBL) sudah aktif. Dengan demikian dalam proses belajar mengajar siswa lebih aktif dan lebih banyak berpartisipasi. Selanjutnya data mengenai hasil belajar siswa dapat dilihat pada Tabel 2.

Tabel 2. Data Hasil Belajar Siswa Kelas V

SDN 1 Sembalun Bumbung Tahun Pelajaran 2019/2020

\begin{tabular}{|l|l|c|c|}
\hline No & Hasil belajar & Siklus I & Siklus II \\
\hline 1. & Jumlah siswa & 23 & 23 \\
\hline 2. & Nilai rata-rata & 62,7 & 75,8 \\
\hline 3. & $\begin{array}{l}\text { Jumlah siswa } \\
\text { yang tuntas }\end{array}$ & 15 & 21 \\
\hline 4. & $\begin{array}{l}\text { Jumlah siswa } \\
\text { yang belum } \\
\text { tuntas }\end{array}$ & 8 & 2 \\
\hline 5. & $\begin{array}{l}\text { Presentase } \\
\text { ketuntasan } \\
\text { klasikal }\end{array}$ & $65 \%$ & $91 \%$ \\
\hline 6. & Kategori & $\begin{array}{l}\text { Tidak } \\
\text { Tuntas }\end{array}$ & Tuntas \\
\hline
\end{tabular}

Meningkatnya aktivitas siswa dari siklus I ke siklus II tersebut, maka sangat berpengaruh terhadap peningkatan hasil belajar siswa. Hal ini dapat dilihat dari hasil evalusi belajar siswa seperti yang tertera pada Tabel 2, dimana pemberian tindakan pada siklus I menunjukkan bahwa nilai rata-rata siswa 62,7 dengan persentase ketuntasan klasikal sebesar 65\% ini berarti pada siklus I ketuntasan belajar siswa belum tercapai sesuai dengan yang diharapkan. Hal ini disebabkan guru kurang aktif membimbing dan memberi memotivasi sehingga siswa kurang antusias dalam menerima materi pelajaran, siswa juga kurang berani dalam mengeluarkan pendapat dan bertanya, kurangnya interaksi siswa dengan siswa, dan siswa kurang siap menerima materi pelajaran karena masih banyak yang kurang mengerti dan tidak bertanya tentang kesulitan yang dihadapi.

Mengacu pada perlakuan siklus I, maka dilaksanakusman orang, ini menunjukkan bahwa persentase klasikal yang ditetapkan dalam kriteria keberhasilan penelitian sudah tercapai.

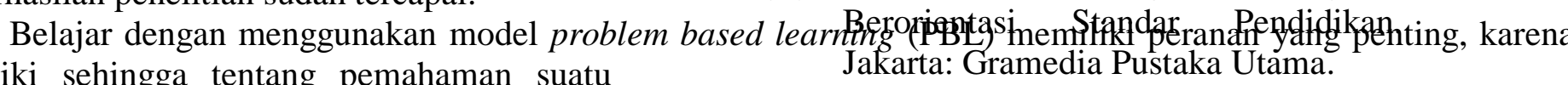
dimiliki sehingga tentang pemahaman suatu konsep dapat diterima dengan baik. Jadi dengan adanya penerapan Strategi pembelajaran ini, siswa tidak lagi pasif dalam pembelajaran dan proses pembelajaranpun tidak lagi monoton. Hal inilah yang menjadikan siswa aktif dan dapat merumuskan konsep-konsep dalam pembelajaran.

\section{KESIMPULAN}

Penerapan model pembelajaran problem based learning (PBL) dengan rancangan pembelajaran siklus II pada penelitian ini pada ketegori baik dan dapat meningkatkan aktivitas keterampilan proses sains pada pelajaran tema 5 siswa kelas IV SDN 1 Sembalun Bumbung Lombok Utara. Hal ini dibuktikan dengan aktivitas siswa pada siklus I sebesar 65\% yang berkategori cukup aktif dan aktivitas siswa pada siklus II sebesar $91 \%$ yang berkategori aktif.

\section{DAFTAR PUSTAKA}

Arikunto, S. 2014. Penelitian Tindakan Kelas. Jakarta: PT. Bumi Aksara.

Bahri, M. 2014. Psikologi Pembelajaran. Surabaya: UIN Sunan Ampel Press.

Kadir, A dan Asrohah, H. 2014. Pembelajaran Tematik. Jakarta: Rajawali Pers.

Kemendikbud. 2013. Materi Pelatihan Guru Implementasikan Kurikulum 2013. Jakarta: Kemendikbud RI.

Kurniasih. 2014. Strategi-Strategi Pembelajaran. Bandung: PT Alfabeta.

Miarso,Yusufhadi. 2007. Menyemai Benih Teknologi Pendidikan.Prenada. Jakarta: Media Group.

Ngalim, P. 2013. Prinsip-prinsip dan Teknik Evaluasi Pengajaran. Bandung: PT Remaja Rosdakarya.

Riyanto, Y. (2010). Paradigma Pembelajaran sebagai Referensi bagi Pendidik dalam Implementasi Pembelajaran yang Efektif dan Berkualitas. Jakrta: Prenada Media Group.
Mengembangkan Profesionalisme Guru. Jakarta: Rajawali Pers.
Sanjaya, W. 2010. Strategi Pembelajaran 
Sireger, E dan Nara, H. 2010. Teori Belajar dan Pembelajaran. Bogor: Penerbit Ghalia Indonesia.

Sudjana, N. 2010. Penilaian Hasi Proses Belajar Mengajar, Bandung: Remaja Rosdakarya. 